\title{
Survey on Demand and Operation Status of Care Farms in South Korea
}

\author{
A-Young Lee', Yun Ah Oh², Seon Ok Kim², Dae-Sik Kim², and Sin-Ae Park ${ }^{1,2}$ * \\ 1 Department of Environmental Health Science, Sanghuh College of Life Science, Konkuk Univ., Seoul 05029, South Korea \\ ${ }^{2}$ Department of Horticultural Therapy, Graduate School of Agriculture and Animal Science, Konkuk Univ., Seoul 05029, South Korea \\ ${ }^{3}$ Department of Agricultural and Rural Engineering, Chungnam National Univ., Daejeon 34134, South Korea
}

\begin{abstract}
This study was conducted to investigate needs and operational status for care farming of education or experience farms in South Korea. A questionnaire made up of 38 questions was developed for this study. The survey was conducted online among owners in education and experience farms (total 264 sites) in Seoul and nine provinces in September 2017. A total of 78 questionnaires were collected and the response rate was $44.6 \%$. As the results, the purposes of farm operation reported as experience $(85.9 \%)$, education $(79.5 \%)$, production of agricultural products $(67.9 \%)$, and healing (47.4\%). Main visitors in education and experience farm were children and adolescents (89.7\%), adults (51.3\%), and families (46.2\%). A farm activity program was mainly provided by a one-time experience using crops (69.2\%), animals (16.7\%), and food processing activity (10.3\%). Fifty percent of the responding farmers received support from the government and the local government such as public relations $(32.5 \%)$, operational funding $(32.5 \%)$, and management consulting $(15.0 \%)$. The lack factor of operating in farms was lower profit system $(24.4 \%)$, poor farm infrastructure $(21.8 \%)$, and lack of promotion and marketing ways (16.7\%). $97.5 \%$ of the respondents reported 'very necessary' and 'necessary' of care farming. Specifically, the care farming service reported that priority should be given to children and adolescents (55.1\%) and people with emotional and behavior disorder (15.4\%). The present study is anticipated to offer the efficient management of care farm and provides reference data of the policy suggestion for care farming setting in South Korea.
\end{abstract}

Keywords: agro-healing, gardening, green care, social farming

\section{Introduction}

Recently, according to the "Sixth industrialization of agriculture" policy of the South Korean government, there has been a growing domestic interest in care farming utilizing the healing characteristics of agriculture, apart from production-oriented agriculture. Care farming is defined as industries and activities that promote the psychological, social, cognitive, and physical health of the people through the use of agricultural or rural resources or related activities and products (Gim et al., 2013). In addition, it provides care farming activities such as horticulture-healing, forest-healing, animal-assisted intervention, and wildness · natural-healing aimed at healing, rehabilitation, education, etc., for the people

\footnotetext{
This work was supported by the research project of the Rural Development Administration (Project title: Research on the design of agro-healing service in agriculture considering life cycle; Project No. PJ012564012017).

Received: December 5, 2017, Revised: December 21, 2017, Accepted: December 26, 2017

First author: A-Young Lee, E-mail: danapre@konkuk.ac.kr, ORCID: 0000-0001-5719-5548

*Corresponding author: Sin-Ae Park, E-mail: sapark42@konkuk.ac.kr, ORCID: 0000-0003-1367-8825 
who need to be recovered (for example, patients, the disabled, and the social misfits) (Di Iacovo and O'Connor, 2009; Haubenhofer et al., 2010).

Europe's advanced countries in care farming have already established the concept, purpose, and public support policies for care farming by accurately grasping the national conditions and needs of their own countries (Hine et al., 2008; Di lacovo and O'Connor, 2009; Dessein and Bock, 2010). Though there have been various attempts to establish and revitalize domestic care farming in South Korea, such as establishing the concept of domestic care farming at the national and private level, investigating domestic situations for and seeking plans for introduction of care farming, surveying care farming contents as well as intention of participation, estimating willingness to pay for the services (Gim et al., 2013; Kim et al., 2016; Lee et al., 2016; Park et al., 2017). Domestic care farming is still at an early stage and multilateral discussions have been made for introduction of care farming system suitable for South Korea (Jeong et al., 2017). In particular, Jeong et al. (2017) reports that the number of farms providing care farming services in South Korea is very low, and domestic care farms show differences in improvement of operation compared to the cases of advanced countries in care farming.

In the meantime, as a part of the policy to overcome the crises in agriculture and rural areas caused by the sharp decline and aging of the rural population, the government has prepared a way to preserve the income source of the domestic farmers and enhance the competitiveness of the rural areas through the introduction of education and experience farms (Kwak et al., 2016). Education and experience farms provide farmers with a variety of experiential activities and educational programs that utilize agricultural and rural resources for farm visitors (Rural Development Administration, 2008). As of February 2015, there are about 524 rural farming education and experience farms in South Korea, showing quantitative growth (Kwak et al., 2016). However, currently, lack of qualitative farm operation such as poor operating conditions and lack of expertise leads to difficulties in attracting customers and low profits, resulting in operational difficulties and therefore the farms had to find new ways to operate successful farms (Lee et al., 2016).

In this regard, domestic education and experience farms and care farming have common in providing various services utilizing agriculture and rural resources, which presents growth potential that existing farms providing education and experience can grow into care farms through introduction of care farming. As a strategy for successful operation of an organization, it is very important to analyze the resources (hardware resources, human resources, and software resources) constituting the organization's operating system (Baek et al., 2002). Therefore, this study was conducted to investigate the current status of education or experience farms for care farming, and further to find out the awareness and demand of farmers on care farming for the settlement and activation of domestic care farms.

\section{Study Method}

\section{Study subject and survey method}

For this study, a total of 246 farmers were selected for the survey as of August 2017, who are providing education, experiences and care farming services in one metropolitan city and nine provinces nationwide (Gyeonggi-do, Gangwon-do, Chungcheongbuk-do, Chungcheongnam-do, Gyeongsangbuk-do, Gyeongsangnam-do, Jeollabuk-do, Jeollanam- do, and Jeju-do). The list of related farms was obtained from "National education Farm" (Rural Development Administration, 2017) and the "Domestic care farming service case report" (National Institute of Horticultural and Herbal Science, 2016) and an online survey was conducted for 14 days from the second to the third week of September 2017. The survey of this study was conducted by the researcher after obtaining consent from the farmers to participate in the questionnaire over the phone, then sending the questionnaire link via mobile and e-mail. In order to investigate the current operation status of domestic education and experience for care farming and awareness and demand of farmers over care farming, a total of 38

2 - Journal of People, Plants, and Environment Vol. 21, No. 1, 2018 
questions were developed based on the questionnaires used in former domestic and overseas studies (Hine et al., 2008; Park et al., 2014; Kim et al., 2016; Jeong et al., 2017; Kim et al., 2017). The questionnaires consisted of 5 items of farmer's demographic information, 28 items of farm operation, 5 items of recognition and requirement of farmer's over care farming. Of the 175 respondents who agreed to participate in the survey, 78 (44.6\%) responded to the questionnaire.

\section{Analysis method}

The questionnaires were collected through the Google questionnaire (https://docs.google.com/forms/u/0/) served by Google, internet portal site. The frequency $(\mathrm{N})$ and the percentage (\%) of the responses were automatically calculated. In addition, the descriptive statistical analysis of additional questionnaire data was conducted by using Microsoft Excel (Office 2007; Microsoft Corp., Redmonf, WA).

\section{Results and Discussion}

\section{Demographic information}

The results of this study are summarized as follows: The number of farmers who participated in the questionnaire was 78 - male 37 (47.4\%), female 41 (52.6\%), and farmer in their 50s are most as 32 (41.0\%) (Table 1). The number of farms operated was 14 (17.9\%) in Gyeonggi-do, 11 (14.1\%) in Chungcheongbuk-do and Jeollabuk-do respectively, and 9 (11.5\%) in Gyeongsangnam-do and Gangwon-do respectively. Those who have operated farms for more than 20 years are most with 26 people (33.3\%), followed by 21 people (26.9\%) between 5 and 9 years and 19 people (24.4\%) between 10 and 14 years. As for educational backgrounds, graduates from university (graduate school) accounted for the highest percentage of academic achievement, posting $70.5 \%$ of the total respondents. Twenty three farmers (44.2\%) majored in agriculture (eg. horticulture, social horticulture, animal husbandry, and food engineering), and 10 of them (19.2\%) majored in horticultural science and social horticulture. In addition, there were 9 people (17.3\%) in the fields of engineering (eg. architectural design and urban engineering), 7 people (13.5\%) in marketing and administration (eg. business administration, trade, and administration), 4 people (7.7\%) in the field of health management and welfare (eg. nursing, clinical pathology, and social welfare), 2 people (3.8\%) in the field of arts and physical education (eg. traditional musicology and arts) and 4 people (7.7\%) in others (eg. religious studies, law, and family management).

\section{Operation status of education, experiences and care farms}

\section{Physical • environmental factors (hardware factor)}

The total area of the farm facilities used for education, experience and care farming was found to be more than $9,917 \mathrm{~m}^{2}$ of land by about $46.2 \%$ of the total respondents (Table 2). In addition, main rural resources utilized are horticultural and agricultural products, accounting for $69.2 \%$, followed by animals $16.7 \%$, food processing activity $10.3 \%$, and others $3.8 \%$.

In the case of the UK, it is reported that the operating area of the care farm was varied from $3,000 \mathrm{~m}^{2}$ to $6,500,000 \mathrm{~m}^{2}$, and the average area was 499,000 $\mathrm{m}^{2}$ (Hine et al., 2008).

Most of domestic farms have facilities such as guidance about education, farming experience, parking, garden, indoors and outdoors educational space, drinking water, and playground facilities, while there are poor installations of animal breeding areas, healing areas or wheelchair ramps designed for the handicapped (Lee et al., 2016). In addition, it has been shown that the physical factors of domestic farming education and experience farmers are lower in terms of mixed 
Table 1. Demographic information of the participated owners in this study $(\mathrm{N}=78)$.

\begin{tabular}{|c|c|c|c|}
\hline Variable & Category & $\mathrm{N}$ & $\%$ \\
\hline \multirow{2}{*}{ Gender } & Male & 37 & 47.4 \\
\hline & Female & 41 & 52.6 \\
\hline \multirow{4}{*}{ Age } & 31 to 40 years old & 3 & 3.8 \\
\hline & 41 to 50 years old & 23 & 29.5 \\
\hline & 51 to 60 years old & 32 & 41.0 \\
\hline & Over 61 years old & 20 & 25.6 \\
\hline \multirow{10}{*}{ Operating area } & Seoul & 1 & 1.3 \\
\hline & Gyeonggi-do & 14 & 17.9 \\
\hline & Gangwon-do & 9 & 11.5 \\
\hline & Chungcheongbuk-do & 11 & 14.1 \\
\hline & Chungcheongnam-do & 3 & 3.8 \\
\hline & Gyeongsangbuk-do & 8 & 10.3 \\
\hline & Gyeongsangnam-do & 9 & 11.5 \\
\hline & Jeollabuk-do & 11 & 14.1 \\
\hline & Jeollanam-do & 5 & 6.4 \\
\hline & Jeju-do & 7 & 9.0 \\
\hline \multirow{5}{*}{ Operating period } & Less than 5 years & 4 & 5.1 \\
\hline & 5 to 9 years & 21 & 26.9 \\
\hline & 10 to 14 years & 19 & 24.4 \\
\hline & 15 to 19 years & 8 & 10.3 \\
\hline & More than 20 years & 26 & 33.3 \\
\hline \multirow{3}{*}{ Education } & Elementary school graduate & 3 & 3.8 \\
\hline & High school graduate & 20 & 25.6 \\
\hline & University and graduate school graduate & 55 & 70.5 \\
\hline \multirow{7}{*}{ Major } & Agriculture & 23 & 44.2 \\
\hline & Engineering & 9 & 17.3 \\
\hline & Management and administration & 7 & 13.5 \\
\hline & Health care and welfare & 4 & 7.7 \\
\hline & Humanities & 3 & 5.8 \\
\hline & Art and physical education & 2 & 3.8 \\
\hline & Others & 4 & 7.7 \\
\hline
\end{tabular}

utilization of animal and forest resources in domestic farms than those of European care farms (Hine et al., 2008; Jeong et al., 2017). It is expected to have a high proportion of installed garden and indoor/outdoor educational space because crops are used as a major resource. In the case of Dutch care farms, there is the complex installation of a variety of caring and convenience facilities for the cared with diversity while the facilities of related farm households in South Korea are 
Table 2. The physical environmental and human resource factors for operating eduction and experience farms.

\begin{tabular}{|c|c|c|c|}
\hline Variable & Category & $\mathrm{N}$ & $\%$ \\
\hline \multicolumn{4}{|c|}{ Physical $\cdot$ environmental factor } \\
\hline \multirow{7}{*}{ Size of farm } & Less than $1,652 \mathrm{~m}^{2}$ & 8 & 10.3 \\
\hline & 1,652 to $3,302 \mathrm{~m}^{2}$ & 8 & 10.3 \\
\hline & 3,305 to $4,955 \mathrm{~m}^{2}$ & 11 & 14.1 \\
\hline & 4,958 to $6,608 \mathrm{~m}^{2}$ & 3 & 3.8 \\
\hline & 6,611 to $8,261 \mathrm{~m}^{2}$ & 6 & 7.7 \\
\hline & 8,264 to $9,914 \mathrm{~m}^{2}$ & 6 & 7.7 \\
\hline & More than $9,917 \mathrm{~m}^{2}$ & 36 & 46.2 \\
\hline \multirow{4}{*}{ Utilized resource type } & Crops & 54 & 69.2 \\
\hline & Animals & 13 & 16.7 \\
\hline & Food processing activity & 8 & 10.3 \\
\hline & Others & 3 & 3.8 \\
\hline \multicolumn{4}{|c|}{ Human resource factor } \\
\hline \multirow{4}{*}{$\begin{array}{l}\text { Worker Employment status } \\
\text { (Multiple responses) }\end{array}$} & Full time & 45 & 57.7 \\
\hline & Part time & 35 & 44.9 \\
\hline & Volunteer & 8 & 10.3 \\
\hline & Self-employed & 18 & 23.1 \\
\hline
\end{tabular}

reported to be insufficient (Jeong et al., 2017). Therefore, in order for education and experience farms to be expanded to care farms, it is necessary to examine the ways to increase farm infrastructure and utilization of farm land considering diversity of care farming services by utilizing more diverse rural resources.

\section{Human resource factor}

The survey on the constituent personnel for education, experience and care farm operation showed that 45 farms (57.7\%) hired resident staff, 35 farms (44.9\%) hired part-time workforce, 18 farms (23.1\%) used their own family members as farm workforce and 8 farms (10.3\%) used volunteers (Table 2). The numbers of resident, part-time, and volunteer employees are all two on average. Occupations and related qualifications of resident workers were $65.5 \%$ for agricultural workers, $22.4 \%$ for horticultural therapists, $19.0 \%$ for education workers, $6.9 \%$ for forest healing professionals and $5.2 \%$ for medical and welfare workers. In the case of part-time workforce, $57.4 \%$ are agricultural workers, $23.4 \%$ are education workers, $21.3 \%$ are horticultural therapists, $12.8 \%$ are medical and welfare workers, and $4.3 \%$ are forest healing professionals. As for volunteers, $37.5 \%$ are educational workers and medical and welfare workers account for $25 \%$, respectively.

In the case of UK care farms, on average, there were five resident workers and five part-time workers and about 12 volunteers (Hine et al., 2008). The occupations of these workers were similar to those of domestic farms surveyed in this study, with education (26\%), agricultural production (23\%), horticulture (16\%) and horticulture workers (7\%). Jeong et al. (2017) also found that experts in various fields are involved in care farms of the Netherlands such as healthcare, welfare, and education, which emphasizes paramount importance of expertise and sufficient experiences about care farming 
services based on agricultural production techniques such as agricultural activities and agricultural resources. Therefore, it is necessary to improve professional ability and train professional workforce in domestic care farming such as horticultural therapist, forest healing instructor, and animal assist therapist. In previous studies (Hong and Lee, 2016) analyzing strategies for cultivating domestic professionals in care farming, research and development such as industryacademy cooperation support, development of healing contents, and effectiveness verification should the top priority and the second priority is reported to build relevant legal and institutional system such as the system for human resource development, implementation system, nationally authorized qualification system and specialist recruitment system for cultivating professional workforce designed to link farmers with leaders in a local community and provide management improvement consulting services, etc.

\section{Internal factor (software factor)}

The results (Table 3) of researching farm operating system and major programs showed that, the main users were children and adolescents (89.7\%) and the main purpose of the operation was experiencing (85.9\%), education (79.5\%), agriculture production (67.9\%), and healing (47.4\%). Farms operated year-round from January to December accounted for $48.6 \%$, majority of the total, while farms with more than 3,000 visitors during the year accounted for $23.1 \%$ ( 18 farms), a relatively high percentage.

The main programs were cooking with crops $60.3 \%$, harvesting crops $47.4 \%$, indoor horticultural activities $43.6 \%$, crop

Table 3. The software factors for operating education and experience farm.

\begin{tabular}{|c|c|c|c|}
\hline Variable & Category & $\mathrm{N}$ & $\%$ \\
\hline \multirow{7}{*}{$\begin{array}{l}\text { Purpose of farm operation } \\
\text { (Multiple responses) }\end{array}$} & Experience & 67 & 85.9 \\
\hline & Education & 62 & 79.5 \\
\hline & Production of agricultural products & 53 & 67.9 \\
\hline & Healing & 37 & 47.4 \\
\hline & Sales of processed products & 31 & 39.7 \\
\hline & Rehabilitation & 4 & 5.1 \\
\hline & Others & 3 & 3.8 \\
\hline \multirow{4}{*}{ Operating period } & All year round & 35 & 48.6 \\
\hline & Except for midwinter & 26 & 36.1 \\
\hline & Spring and fall & 9 & 12.5 \\
\hline & Others & 2 & 2.8 \\
\hline \multirow{8}{*}{$\begin{array}{l}\text { Farm activity program } \\
\text { (Multiple responses) }\end{array}$} & Cooking with the harvest & 47 & 60.3 \\
\hline & Harvesting crops & 37 & 47.4 \\
\hline & Indoor horticultural activity & 34 & 43.6 \\
\hline & Cultivating crops & 25 & 32.1 \\
\hline & Animal experience & 17 & 21.8 \\
\hline & Forest experience & 17 & 21.8 \\
\hline & Farm working & 10 & 11.5 \\
\hline & Others & 4 & 5.1 \\
\hline
\end{tabular}


Table 3. Continued.

\begin{tabular}{|c|c|c|c|}
\hline Variable & Category & $\mathrm{N}$ & $\%$ \\
\hline \multirow{7}{*}{ Program duration } & A one-time experience & 58 & 74.4 \\
\hline & Short-term program (less than 3 months) & 3 & 3.8 \\
\hline & Mid-term program ( 3 to 6 months) & 3 & 3.8 \\
\hline & Long term program (over 6 months) & 2 & 2.6 \\
\hline & Short-term stay (less than a week) & 4 & 5.1 \\
\hline & Mid-term stay ( 1 week to 1 month) & 1 & 1.3 \\
\hline & Others & 7 & 9.0 \\
\hline \multirow{6}{*}{ Time per one session } & Less than 30 minutes & 1 & 1.3 \\
\hline & 30 to 60 minutes & 6 & 7.7 \\
\hline & 60 to 90 minutes & 18 & 23.1 \\
\hline & 90 to 120 minutes & 26 & 33.3 \\
\hline & 120 to 150 minutes & 15 & 19.2 \\
\hline & Over 150 minutes & 12 & 15.4 \\
\hline \multirow{10}{*}{$\begin{array}{l}\text { Main visitors } \\
\text { (Multiple responses) }\end{array}$} & Preschoolers & 34 & 43.6 \\
\hline & Children and adolescents & 70 & 89.7 \\
\hline & Adults & 40 & 51.3 \\
\hline & Elderly & 20 & 25.6 \\
\hline & Family & 36 & 46.2 \\
\hline & People with emotional and behavior disorder & 17 & 21.8 \\
\hline & People with physical illness & 8 & 10.3 \\
\hline & People with mental illness & 7 & 9.0 \\
\hline & People with brain disease & 3 & 3.8 \\
\hline & Others & 5 & 6.4 \\
\hline \multirow{7}{*}{ Number of visitors per year } & Less than 500 people & 11 & 14.1 \\
\hline & 500 to 1,000 people & 15 & 19.2 \\
\hline & 1,000 to 1,500 people & 12 & 15.4 \\
\hline & 1,500 to 2,000 people & 10 & 12.8 \\
\hline & 2,000 to 2,500 people & 5 & 6.4 \\
\hline & 2,500 to 3,000 people & 7 & 9.0 \\
\hline & More than 3,000 people & 18 & 23.1 \\
\hline \multirow{8}{*}{ Yearly income through program } & Less than $10,000,000$ won & 15 & 19.2 \\
\hline & $10,000,000$ to $20,000,000$ won & 16 & 20.5 \\
\hline & $20,000,000$ to $30,000,000$ won & 18 & 23.1 \\
\hline & $30,000,000$ to $40,000,000$ won & 6 & 7.7 \\
\hline & $40,000,000$ to $50,000,000$ won & 4 & 5.1 \\
\hline & $50,000,000$ to $60,000,000$ won & 4 & 5.1 \\
\hline & $60,000,000$ to $70,000,000$ won & 3 & 3.8 \\
\hline & More than $70,000,000$ won & 12 & 15.4 \\
\hline
\end{tabular}


Table 3. Continued.

\begin{tabular}{|c|c|c|c|}
\hline Variable & Category & $\mathrm{N}$ & $\%$ \\
\hline \multirow{9}{*}{$\begin{array}{l}\text { Public-relations type } \\
\text { (Multiple responses) }\end{array}$} & Website / social media & 59 & 75.6 \\
\hline & Self-production & 26 & 33.3 \\
\hline & Public office brochure & 23 & 29.5 \\
\hline & Local festival and event & 22 & 28.2 \\
\hline & Internet & 8 & 10.3 \\
\hline & $\mathrm{TV} /$ radio & 4 & 5.1 \\
\hline & Newspaper / magazine & 3 & 3.8 \\
\hline & Others & 1 & 1.3 \\
\hline & Not promoting & 8 & 10.3 \\
\hline
\end{tabular}

cultivation $32.1 \%$, animal experience and forest experience $21.8 \%$ respectively, indicating that programs mainly used horticultural crops. It was reported that programs were operated mostly in the form of one-time experience (74.4\%), and the 90-120 minute-long activity (33.3\%) per session was often performed. Most of the annual income earned from such programs were between more than 10 million won and less than 30 million won (43.6\%). In addition, there were 12 farm households (15.4\%) who earned more than 70 million won, while there are low-income farms with less than 10 million (19.2\%) (Table 3).

On the other hand, about $89.7 \%$ of farmers responded that they advertised farms, and $75.6 \%$ of them used personal websites and social media most (Table 3). The certification by national agencies was carried out in 70 farms $(89.7 \%)$ of total respondents. The certification type varies from 58 sites (67.4\%) for quality certification as educational farm (Rural Development Administration) to 9 farms (10.5\%) for the rural convergence project (6th industry) (Ministry of Agriculture, Food and Rural Affairs) to five farms (5.8\%) for good rural food life experience space (Ministry of Agriculture, Food and Rural Affairs) and 4 places (4.7\%) for educational donation experience certification (Ministry of Education). Most of these national certification schemes were mainly introduced from 2014 to 2016.

Of the total 78 farm households participating in this study, 39 farms, the half of the total (50.0\%) received external

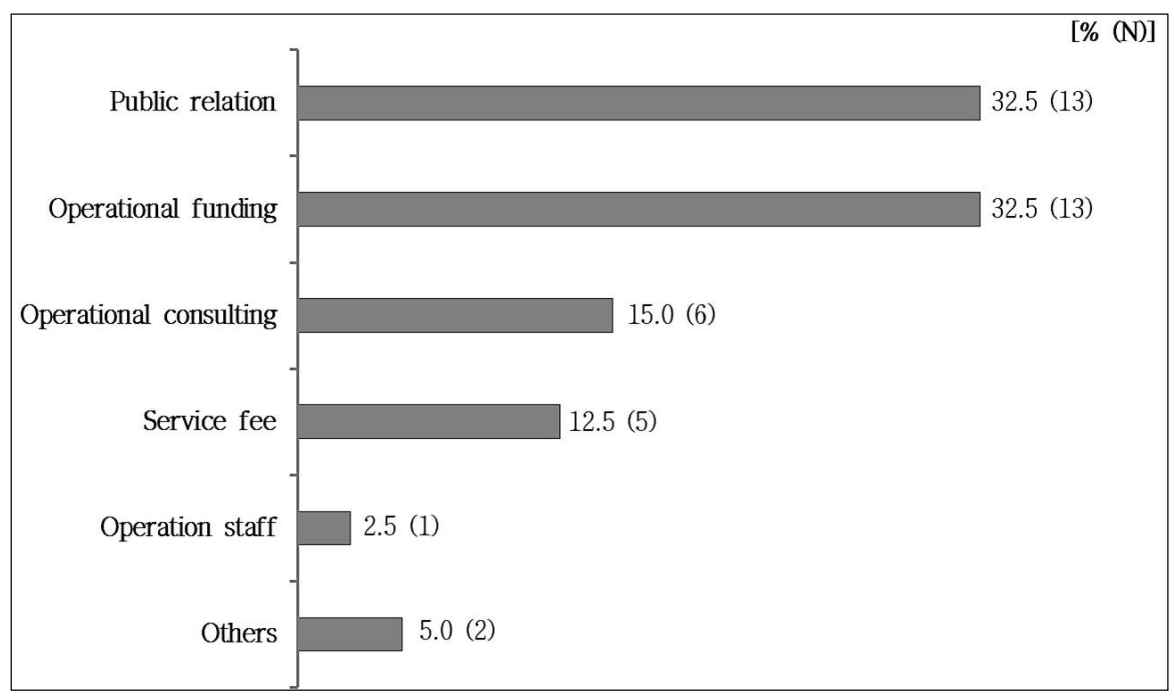

Figure 1. Type of external supporting for farm operation. 
support and all were supported by government agencies and local governments (eg. Rural Development Administration and Agricultural Technology Center). The type of support was mainly composed of support in operating funds and public relations (Fig. 1).

The result of research on the main purpose of the related farm households in 2015 showed that the farm households with the purpose of education accounted for $35.2 \%, 24.6 \%$ for the agricultural products sales, $10.6 \%$ for recreation and $9.0 \%$ for exchanges between urban and rural areas (Lee et al., 2016). In a previous study (Gim et al., 2013), which was conducted through focus group interviews to find ways to develop care farming in South Korea. It was suggested that the purpose of care farming in South Korea should be education, healing, and social rehabilitation.

On the other hand, there is high tendency to use care farming for healing and recreation purposes as well as education and experiences. In particular $77.3 \%$ of the patients are more likely to participate in care farming than $64.7 \%$ of ordinary people (Park et al., 2017). In addition, Jeong et al. (2017) compared the major uses of Dutch care farms and domestic care farms, which emphasizes the importance of expanding the scope of the subject of care in domestic farms so that they can care even those suffering from brain damage and mental illness. Accordingly, it is necessary to establish the purpose of the care farm which are suitable for the domestic situation and reflect the opinions of the people about the care farming demand in order for the education and experience farms to be expanded to care farms.

It has been reported that farms in European countries such as the Netherlands, Belgium, and the UK, which are care farming advanced countries, receive support for farm operations from government agencies, community organizations, and charities (Goris and Weckhuysen, 2006; Hassink et al., 2007; Hine et al., 2008). In the case of the Netherlands, attempts have been made to provide service fees for using care farms as premiums through private health insurance schemes by including care farming in the public medical service sector (Hassink et al., 2013). Therefore, unlike the support for European care farms, domestic farms are supported only by the related organizations. Therefore, in order to expand and operate the care farms smoothly, it is necessary to expand the support not only from agricultural related organizations but also from health, welfare, and medical related institutions. It is thought that various government ministries should be able to recognize the necessity of introducing domestic care farming and provide a way to support care farmers.

\section{Satisfaction and difficulties in operation of education and experience farms}

As a result of surveying farmers' satisfaction with farm operation, farmers in education, experience and care farms

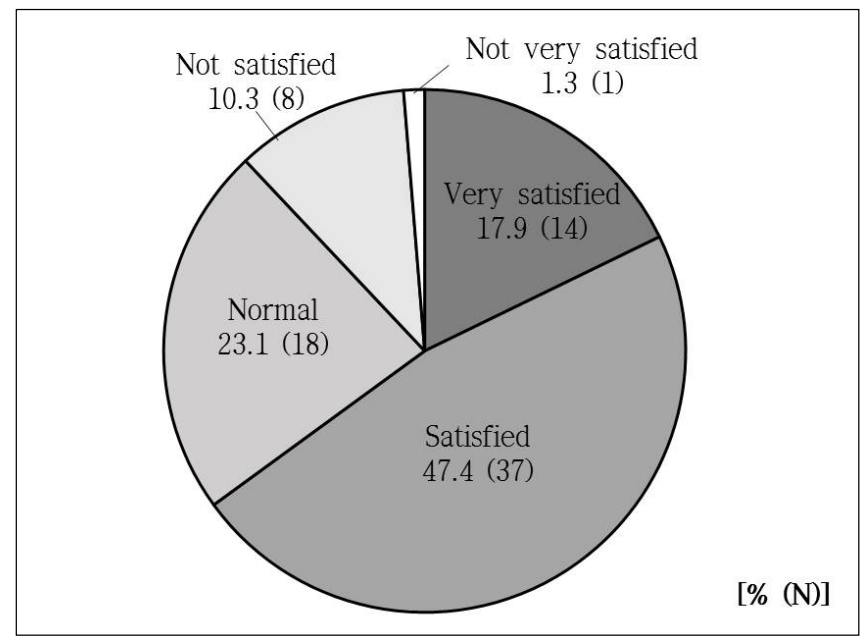

Figure 2. Operational satisfaction of education and experience farms. 


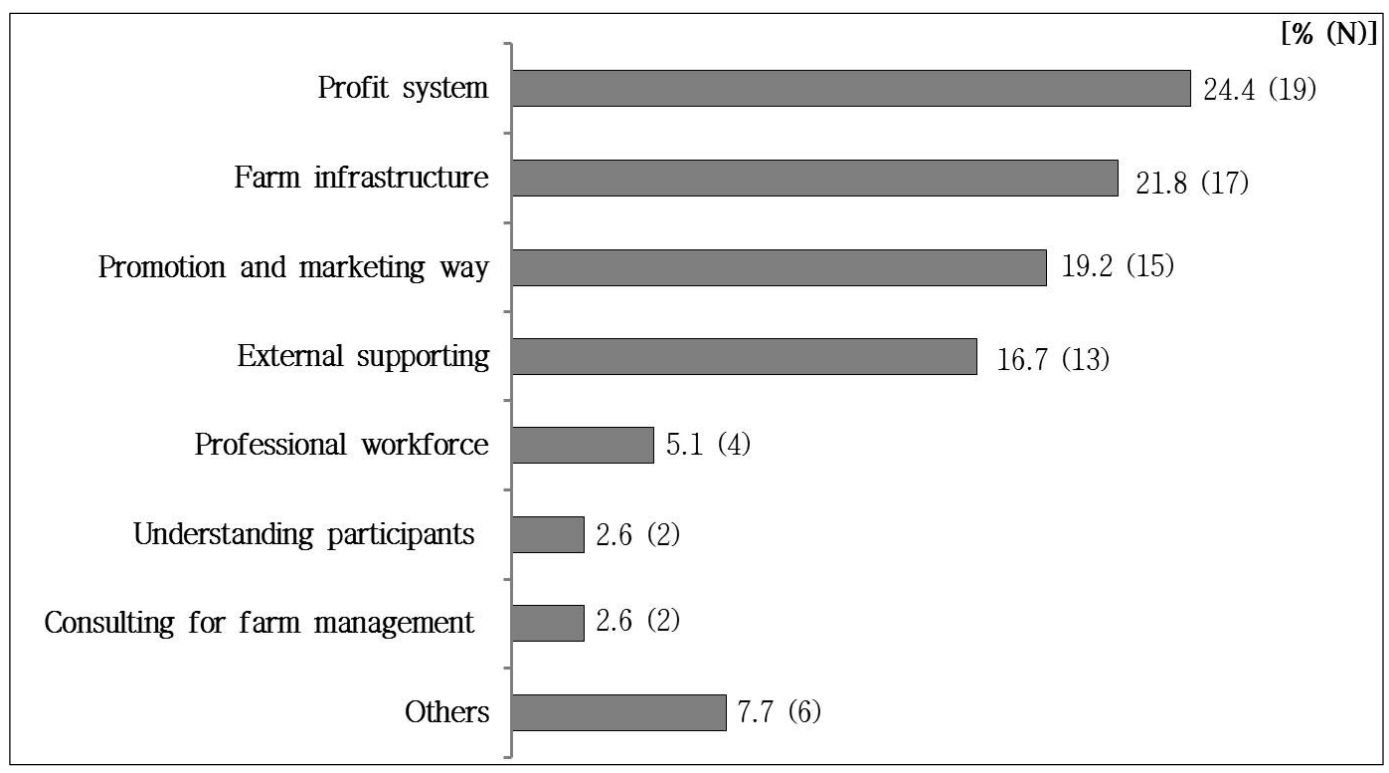

Figure 3. The lack factor of operating education and experience farms.

showed higher satisfaction, with more than $65 \%$ of respondents saying "very satisfied" and "satisfied" (Fig. 2). The difficulties faced in operating the farm were low profit structure (24.4\%), poor farm facilities and surrounding environment (21.8\%), and lack of means of publicity (19.2\%) (Fig. 3).

\section{Demand for care farming}

The results of the survey on the farmers of education and experience farms, who participated in the questionnaire on the necessity of care farming services, showed that $66.7 \%$ said "very necessary", $30.8 \%$ "necessary", and $2.6 \%$ "normal" (Table 4). According to the results of survey on the subjects that need the care farming service with the priority in South Korea, it was found that $55.1 \%$ said "children and adolescents", $15.4 \%$ said "those with emotional and behavioral disorders", $10.3 \%$ said "middle-aged" and $5.1 \%$ said "elderly people."

In the meantime, $89.7 \%$ of respondents were asked whether they intend to operate care farms, $61.5 \%$ said "very wished", $28.2 \%$ said they intend to operate the farms, $7.7 \%$ said "normal", and $2.6 \%$ said they do not want to operate it, indicating that most of them have intention to expand their farms to care farms. When asked what are the most urgent to be improved in expanding operation to care farms, $35.9 \%$ of the respondents answered "expanding economic support", $21.8 \%$ said "improving media of public relations", $17.9 \%$ said "improving staff professionalism", 15.4\% said "expanding facility for healing agriculture", and 7.7\% said "improving care farm's accessibility" (Table 4).

In a survey conducted to investigate the intention of expanding care farming to farmers in domestic education farms in $2015,95.2 \%$ of the farmers wanted to introduce care farming into existing farms reported a very high demand (Lee et al., 2016), which is similar to this study. In addition, in order to grasp the perception and demand of care farming nationwide the survey researchers were sent to Seoul special city and five metropolitan cities (Ulsan, Gwangju, Daegu, Daejeon, and Incheon) $89.3 \%$ out of all the respondents (1,302 people) answered that they need to introduce care farming in South Korea (Park et al., 2017). Therefore, it is considered that the demand for the introduction of domestic care farming is highly perceived by the related workers and the general public.

The farmers who participated in this study ranked children and adolescents as the first priority to be provided with care 
Table 4. Awareness and needs for care farming among education and experience farm owners.

\begin{tabular}{|c|c|c|}
\hline Variable & $\mathrm{N}$ & $\%$ \\
\hline \multicolumn{3}{|l|}{ Need of care farming } \\
\hline Very necessary & 52 & 66.7 \\
\hline Necessary & 24 & 30.8 \\
\hline Normal & 2 & 2.6 \\
\hline \multicolumn{3}{|l|}{ Priority application subject of care farming } \\
\hline \multicolumn{3}{|l|}{ General } \\
\hline Preschoolers (under six years old) & 1 & 1.3 \\
\hline Children and adolescents ( 7 to 18 years old) & 43 & 55.1 \\
\hline Adulthood (19 to 35 years old) & 3 & 3.8 \\
\hline Middle aged (36 to 65 years old) & 8 & 10.3 \\
\hline Elderly (over 65 years old) & 4 & 5.1 \\
\hline People with emotional and behavior disorder & 12 & 15.4 \\
\hline Others & 7 & 9.1 \\
\hline \multicolumn{3}{|c|}{ Operational decision of care farm } \\
\hline Very wished & 48 & 61.5 \\
\hline Wished & 22 & 28.2 \\
\hline Normal & 6 & 7.7 \\
\hline Not wished & 2 & 2.6 \\
\hline \multicolumn{3}{|c|}{ Improvements for care farm operation } \\
\hline Expanding economic support & 28 & 35.9 \\
\hline Improving media of public relations & 17 & 21.8 \\
\hline Improving staff professionalism & 14 & 17.9 \\
\hline Expanding facility for care farming & 12 & 15.4 \\
\hline Improving care farm's accessibility & 6 & 7.7 \\
\hline
\end{tabular}

farming services, which were the same as the main visitors of the current farms (Table 3). Lee et al. (2016), which was conducted about operation status of education farm in 2015, showed the same results as in this study. These results suggest that farmers who currently operate education and experience farms are profit groups (Berry and Wilcox, 2015), an organized group that tries to influence the public policy by sharing the same goal. It can be said that they can play a role of social group so that the policy initiative and proposal for the activation and fixation of care farming can be actively carried out.

In order to improve the support system for farm operation, it is necessary to set up a specialized and dedicated organization to organize and support the networks among the workers in care farming, government agencies, insurance companies, and related organizations (Eweg and Hassink, 2011; Gim et al., 2013). Furthermore, as in Europe's advanced countries of care farming, the standards for domestic care farming should be clearly set up, based of which guidelines for the operation of care farms are provided, so that the introduction of care farming in existing education and experience farms can be successfully carried out (Jeong et al., 2017). 


\section{Conclusion}

The purpose of this study was to investigate the current state of education, experience and care farms in Korea, and figure out the demand of care farming among farmers by conducting a survey on farmers in a total of 78 farms operating education, experiences and care farms in Korea. Perception and demand for care farming were very high among these farmers. In particular, the majority (89.7\%) of the farmers want to expand to care farms through the introduction of care farming. As a result of analyzing the operating system of the education and experience and care farms, $46.2 \%$ of the farmers use the area of more than $9,917 \mathrm{~m}^{2}$, and mostly they make the best use of rural resources such as horticultural and agricultural crops $(69.2 \%)$. To run farm, they are utilizing resident staff (45 places, 57.7\%), part-time workforce (35 places, $44.9 \%$ ), family members ( 18 places, $23.1 \%$ ), and volunteers ( 8 places, $10.3 \%$ ), according to the survey. In the case of software factor, the survey showed that experiences (85.9\%) and education (79.5\%) are mostly provided especially for children and adolescents (89.7\%) and most of programs are made up of one-time experience programs (74.4\%) focusing on indoor and outdoor horticultural activities for $85.9 \%$. There have been various aspects to be improved or considered in order to expand from existing farms to care farms. The result of this study is considered to be used as an important reference data when establishing a plan to expand the existing education, experience, and care farm infrastructure for the settlement and activation of domestic care farming.

\section{References}

Baek, S.J., C.K. Chae, H.S. Kim, and J.S. Jeon. 2002. Human resources development through regional innovation system. Sejong, Korea: Korea Research Institute for Vocational Education and Training. Retrieved from http://www.krivet.re.kr/ $\mathrm{ku} / \mathrm{da} / \mathrm{kuBAAVw}$.jsp?gn=E1-E120130795

Berry, J.M. and C. Wilcox. 2015. The interest group society. NewYork, USA: Little, Brown.

Dessein, J. and B. Bock. 2010. The economics of green care in agriculture. Loughborough, UK: Loughborough Univ.

Di Iacovo, F. and D. O'Connor. 2009. Supporting policies for social farming in europe: Progressing multifunctionality in responsive rural areas. Firenze, Italy: Arsia.

Eweg, H.P.A. and J. Hassink. 2011. Business models of green care in the Netherlands. Sao Paulo: FEA. Retrieved from http://library.wur.nl/WebQuery/wurpubs/fulltext/175712

Gim, G.M., J.H. Moon, S.J. Jeong, and S.M. Lee. 2013. Analysis on the present status and characteristics of agro-healing in Korea. Agric. Ext. Dev. 20(4):909-936. DOI: 10.12653/jecd.2013.20.4.0909

Goris, K. and H. Weckhuysen. 2006. Farming for health- The situation in Flanders. In: HASSINK J., VAN DIJK M. (eds) Farming for health. Springer, Dordrecht. DOI:10.1007/1-4020-4541-7_14

Hassink, J., C. Zwartbol, H.J. Agricola, M. Elings, and J.T.N.M. Thissen. 2007. Current status and potential of care farms in the Netherlands. NJAS-Wagening. J. Life Sci. 55(1):21-36. DOI: 10.1016/S1573-5214(07)80002-9

Hassink, J., J. Grin, and W. Hulsink. 2013. Multifunctional agriculture meets health care: Applying the multi-level transition sciences perspective to care farming in the Netherlands. Sociol. Rural. 53(2):223-245. DOI: 10.1111/j.1467-9523.2012.00579.x

Haubenhofer, D.K., M. Elings, J. Hassink, and R.E. Hine. 2010. The development of green care in western european countries. EXPLORE: J. Sci. Heal. 6(2):106-111. DOI: 10.1016/j.explore.2009.12.002

Hine, R., J. Peacock, and J.N. Pretty. 2008. Care farming in the UK: Evidence and opportunities. Report for the National Care Farming Initiative (UK): University of Essex. Retrieved from https://www.slideshare.net/ElisaMendelsohn/ care-farming-in-the-uk-evidence-and-opportunities?qid=05da74e3-88e1-4ffb-af9f-ccd6d3b73197\&v=\&b=\&from_search=1

Hong, J.Y. and B.O. Lee. 2016. Analysis of policy priorities for training agro-healing experts using the AHP method. Agric. Ext. Dev. 23(4):419-429. DOI: 10.12653/jecd.2016.23.4.0419

12 - Journal of People, Plants, and Environment Vol. 21, No. 1, 2018 
Jeong, S.J., J. Hassink, G.M. Gim, S.A. Park, and S.O. Kim. 2017. Status and actual condition analysis for current operational cases of care farms in South Korea. J. People Plants Environ. 20(5):421-429. DOI: 10.11628/ksppe.2017.20.5.421

Kim, D.S., S.M. Choi, G.J. Lee, S.M. Koo, W.L. Lee, B.J. Park, S.J. Bae, K.C. Son, S.A. Park, Y.J. Kim, E.J. Jo, Y.T. Kim, and H.J. Lee. 2016. Feasibility study on green agriculture healing complex project. Naju, Korea: Korea Rural Community Corporation. Retrieved from http://library.mafra.go.kr/skyblueimage/8374.pdf

Kim, J.E., D.S. Kim, and J.S. Ryu. 2017, October. A survey of awareness and demand for the green care services: Focused on people with disabilities and their community practitioners. Proceedings of Korean Society of Rural Planning Conference, Jeonju, Korea.

Kwak, B.J., G.S. Noh, and H.K. Shin. 2016. Study on the factors affecting visitor's attitude and behavior intention to visit educational farms. J. Korean Soc. Rural Planning 22(1):37-48. DOI: 10.7851/ksrp.2016.22.1.037

Lee, S.M., G.M. Gim, S.H. Jeong, and Y.J. Kim. 2016. A strategy for introducing the healing program through a requirements survey of operating condition and healing experience contents in education farms. J. Korean Soc. People Plants Environ. 19(5):417-426. DOI: 10.11628/ksppe.2016.19.5.417

National Institute of Horticulture and Herbal Science. 2016. Service of care farms case report. Jeonju, Korea: Rural Development Administration. Retrieved from http://203.241.55.164/ezpdf/customLayoutNew3.jsp?contentId=2F2F49 3A2F2F646C5F696D6167652F494D472F36302F2F3030303030303239363138352F534552564943452F3030303030 $303239363138355 \mathrm{~F} 30312 \mathrm{E} 504446$

Park, D.B., L.H. Cho, K.L. Do, E.H. Son, J.H. Chae, K.H. Lee, J.Y. Yoon, and H.S. Seo. 2014. Practical approaches for vitalizing educational farms(Report no. PJ008653). Jeonju, Korea: National Institute of Agriculture Science. Retrieved from http://www.ndsl.kr/ndsl/commons/util/ndslOriginalView.do?dbt=TRKO\&cn=TRKO201400011135\&rn=\&url= \&page Code=PG18

Park, S.A., A.Y. Lee, G.J. Lee, W.L. Lee, S.J. Bae, B.J. Park, and D.S. Kim. 2017. A study of awareness and needs for care farming in South Korea. J. People Plants Environ. 20(1):19-24. DOI: 10.11628/ksppe.2017.20.1.019

Rural Development Administration. 2008. Educational farm map using manual work. Suwon, Korea: Rural Development Administration. Retrieved from http://www.google.co.kr/url?sa=t\&rct=j\&q=\&esrc=s\&source=web\&cd=2\&cad=rja\&uact= 8\&ved=0ahUKEwiMq_rUn7jYAhUHybwKHSAWB6cQFggwMAE\&url=http\%3A\%2F\%2Fwww.prism.go.kr\%2Fho mepage\%2FresearchCommon\%2FdownloadResearchAttachFile.do\%3Bjsessionid\%3DD4667BF90BD69A1C552564 8FC6CC735C.node02\%3Fwork_key\%3D001\%26file_type\%3DCPR\%26seq_no\%3D001\%26pdf_conv_yn\%3DN\%26 research_id\%3D1390000-200700009\&usg=AOvVaw12gscgQM2fv11nRH9i1BSW

Rural Development Administration. 2017. Rural education farms. Retrieved from http://www.nongsaro.go.kr/portal/ps/ psz/psza/contentMain.ps?menuId=PS03965 